\title{
Economics and Adoption of Recommended Cultivation Practices by Seasamum Growers
}

\author{
K. Shivaramu ${ }^{1 *}$, M.A. Murthy ${ }^{2}$ and N. Papanna ${ }^{3}$ \\ ${ }^{1}$ Information Specialist, Directorate of Extension, University of Agricultural Sciences, \\ Hebbal, Bengaluru, Karnataka, India, Pin-560 024, E-mail: \\ ${ }^{2}$ Directorate of Extension, University of Agricultural Sciences, Hebbal, Bengaluru, \\ Karnataka, India, Pin-560 024, E-mail:murthy526.mudd@gmail.com \\ ${ }^{3}$ Directorate of Extension, University of Agricultural Sciences, Hebbal, Bengaluru, \\ Karnataka, India \\ *Corresponding author
}

\section{Keywords}

Seasamum,

Adoption,

Recommended

cultivation

practices, Returns,

Constrains

Article Info

Accepted:

22 July 2019

Available Online:

10 August 2019

\section{A B S T R A C T}

The study was conducted during 2018-19 in Mandya district of Karnataka State, India. The pre-tested interview schedule was used to collect the data from 120 Seasamum growers through personal interview method. The collected data was tabulated and analyzed using percentages, correlation and regression. As high as 44.17 per cent of Seasamum growers belonged to medium level adoption category, 35.00 per cent to low adoption category and 20.83 per cent belonged to high adoption category. Majority of the Seasamum growers completely adopted the recommended cultivation practices such as, selection of suitable soil, time of planting, recommended depth of planting, inter cultivation, hand weeding, thinning for maintaining plant population, time of harvesting and post harvest practices. Further, majority of Seasamum growers partially adopted the recommended cultivation practices such as, recommended quantity of seed rate, application of recommended quantity of FYM, time of application of FYM / compost, application of recommended quantity of nitrogen, phosphorus and potassium fertilizers,, recommended spacing, recommended yield and recommended storage practices. In addition, majority of the Seasamum growers not adopted the recommended cultivation practices such as, recommended varieties, application of recommended quantity of micro nutrients, seed treatment with recommended fungicide and application of recommended herbicide. The return per rupee of expenditure was 1.14. The major constraints expressed by Seasamum growers were low price, non availability of recommended varieties, non availability of high yielding varieties, lack of market information, lack of minimum support price, non availability of micro nutrients in smaller quantities and un scientific crop insurance.

\section{Introduction}

Seasamum called as 'queen' of oilseeds by virtue of its excellent oil quality and considered as one of the oldest oilseed crop. Seasamum is highly beneficial as it contains $42-50 \%$ oil and the oil contains 42.00 per cent essential Linoleic acid, 25\% Protein and 16- 
18\% Carbohydrates. Moreover premium quality edible and medicinal oil can be extracted from Seasamum, which can be conserved for a long time. Seasamum oil cake is good feed for poultry, fish, cattle, goat and sheep. Unfortunately, the major obstacle to Seasamum crop expansion is low seed yield which results due to lack of non-shattering, water logged, disease and insect resistant varieties. The crop is now grown in a wide range of environments, extending from semiarid tropics and subtropics to temperate regions. Consequently, the crop has a large diversity in cultivars and cultural systems. India is the largest producer $(890,000$ metric tons) of Seasamum in the world. It also ranks first in the world in terms of Seasamum growing area $(24 \%)$. Perhaps the productivity increase is $7 \mathrm{~kg} / \mathrm{ha}$ per year in India, $13 \mathrm{~kg} / \mathrm{ha}$ per year in Ethiopia and $22 \mathrm{~kg} / \mathrm{ha}$ per year in China. Clearly, the level and rate of increase of yield per hectare of Seasamum in China is more than 50\% higher than in Ethiopia.

The potential yield of Seasamum is still much higher than actual yield, as much damage occurs by pests and diseases, insufficient weed control, high levels of mono cropping, lack of mechanization. The major Seasamum growing states in India are Gujarat, Madhya Pradesh, Tamil Nadu, Maharashtra and Karnataka. In Karnataka Seasamums being grown in an area of 0.45 lakh hectare with a production of 0.22 lakh tones. The major Seasamum growing districts are Mysore, Gulbarga and Mandya. In general, average productivity of Seasamum continues to be lower (144 to $234 \mathrm{~kg} / \mathrm{ha}$ ) than expected from agricultural technology for the last 20 years, mainly due to its cultivation on marginal lands, poor management and without inputs except seed. The major factors responsible for lower yield are inappropriate production practices. Hence, the present study was undertaken with following specific objectives. Further, it will helps in understanding and devising appropriate practices to tackle the problems more efficiently.

To analyze profile characteristics of Seasamum growers.

To study the Adoption of Specific Recommended Cultivation Practices by Seasamum growers.

To know the Relationship between Profile Characteristics of Seasamum growers and Adoption of recommended Seasamum cultivation practices.

To Analyze the Economics of Seasamum Cultivation; and

To document the Constraints Expressed by Seasamum growers

\section{Materials and Methods}

The study was conducted during 2018-19 in Mandya district of Karnataka State, India. The district was purposively selected because it is one of the major Seasamum growing district in Karnataka.

In the district Pandavapura and Nagamangala taluks were purposefully selected since these are major Seasamum growing taluks. In each selected taluk, three villages were randomly selected. In each selected village the list of Seasamum growing farmers was prepared in consultation with the officials of Karnataka State Department of Agriculture (KSDA) and Krishi Vigyan Kendra (KVK), Mandya.

From such a list 20 Seasamum growing farmers were randomly seleted from each village Thus, a total of 120 respondents constituted the sample for the study. The schedule was developed in consultation with scientists and extension workers. The pretested interview schedule was used to collect the data through personal interview method. The collected data was tabulated and analyzed using percentages, correlation and regression. 


\section{Results and Discussion}

\section{Profile characteristics of Seasamum growers}

The data in Table-1 reveals that as high as 45.00 per cent of Seasamum growers belonged to middle age group, 50.00 per cent had studied up to primary school, 54.16 per cent were belonged to medium family size group, 85.83 per cent mainly dependent on agriculture, 68.34 per cent belonged to smaller livestock (1-4 animals) group, 56.67 per cent were marginal farmers, 48.33 per cent were belonged to medium annual income group. 47.50 per cent had medium level of farm experience, 43.34 per cent had medium level of economic motivation, 46.67 per cent had low level of cosmopoliteness, 37.50 per cent had low extension contact, 45.83 per cent had medium level of mass media participation, 40.84 per cent had low level of organizational participation and 46.67 per cent had medium level of aspiration.

\section{Overall adoption of recommended cultivation practices by seasamum growers}

The data in Table- 2 reveals that as high as 44.17 per cent of Seasamum growers belonged to medium level adoption category followed by 35.00 per cent belonged to low adoption category and 20.83 per cent belonged to high adoption category.

\section{Adoption of specific recommended cultivation practices by seasamum growers}

The results in Table-3 reveals that majority of the Seasamum growers completely adopted the recommended cultivation practices such as, selection of suitable soil $(65.00 \%)$, time of planting (91.67\%), recommended depth of planting (73.33\%), inter cultivation (69.16\%), hand weeding $(82.50 \%)$, thinning for maintaining plant population $(65.83 \%)$, time of harvesting (92.50\%) and post harvest practices $(79.17 \%)$. Further, majority of the Seasamum growers partially adopted the recommended cultivation practices such as, recommended quantity of seed rate $(90.00 \%)$, application of recommended quantity of FYM $(82.50 \%)$, time of application of FYM/ compost $(84.67 \%)$ application of recommended quantity of nitrogen fertilizers (73.33\%), phosphorus $(72.50 \%)$ and potash $(85.83 \%)$, recommended spacing $(89.17 \%)$, recommended yield $(74.17 \%)$ and recommended storage practices $(58.33 \%)$. In addition, majority of the Seasamum growers not adopted the recommended cultivation practices such as, recommended varieties $(67.50 \%)$, application of recommended quantity of micro nutrients (91.67\%), seed treatment with recommended fungicide (83.34 $\%)$ and application of recommended herbicide $(100.00 \%)$.

Relationship between profile characteristics of seasamum growers and adoption of recommended seasamum cultivation practices

The data in Table-4 reveals that there was a positive and significant relationship at one per cent level of probability between occupation, farming experience, economic motivation, cosmopoliteness and level of aspiration with their adoption of recommended cultivation practices by Seasamum growers. Further the variables such as live stock possession and annual income had positive and significant relationship at five per cent level with their adoption of recommended cultivation practices by Seasamum growers. Where as age, education, family size, size of land holding, extension contact, mass media participation and organizational participation had non significant relationship with their adoption of recommended cultivation practices by Seasamum growers. 
Contribution of Profile characteristics of Seasamum growers and Adoption of recommended cultivation practices

The Table-5 explains the contribution of independent variables in extent of adoption of recommended cultivation practices by Seasamum growers to their adoption. The results accounted that independent variables viz., age, live stock possession, economic motivation, cosmopoliteness and level of aspiration had significantly contributed to the extent of adoption of recommended cultivation practices in Seasamum by Seasamum growers. The $\mathrm{R} 2$ value specified that all the 14 independent variables had contributed to the tune of 0.344 per cent of variation in extent of adoption of recommended cultivation practices by Seasamum growers.

\section{Economics of seasamum cultivation}

A close look at Table 6 reveals that on an average the cost of Seasamum production per hectare was Rs.15,570 /-. The grass returns was Rs.33,750/- and net returns was Rs.
17,980 per/ hactare. The return per rupee of expenditure was 1.14. The cost on land preparation was $(24.82 \%)$ ranked first, farm yard manure (18.38\%) ranked second, fertilizers $(10.85 \%)$ ranked third, harvesting $(10.78 \%)$ ranked fourth, sowing $(8.47 \%)$ ranked fifth, plant protection measures and packing and transportation (6.98\%) ranked sixth, inter cultivation $(5.70 \%)$ ranked seventh, weeding $(4.45 \%)$ ranked eighth and seeds $(2.59 \%)$ ranked ninth.

\section{Constraints expressed by Seasamum growers}

The major constraints expressed by Seasamum growers in production of seasamum (Table-7) were low price (Rank I), non availability of recommended varieties (Rank II), non availability of high yielding varieties (Rank III), lack of market information (Rank IV), lack of minimum support price (Rank V), non availability of micro nutrients in smaller quantities (Rank VI) and un scientific crop insurance (Rank VII).

Table.1 Profile Characteristics of Seasamum growers

\begin{tabular}{|c|c|c|c|c|}
\hline \multirow{2}{*}{$\begin{array}{l}\text { Sl. } \\
\text { No }\end{array}$} & \multirow[t]{2}{*}{ Variable } & \multirow[t]{2}{*}{ Characteristic } & \multicolumn{2}{|c|}{ Respondents } \\
\hline & & & Number & Percent \\
\hline \multirow{3}{*}{1} & \multirow[t]{3}{*}{ Age } & Young $=(<30)$ & 20 & 16.67 \\
\hline & & Middle $=(30-50)$ & 54 & 45.00 \\
\hline & & Old $=(>50)$ & 46 & 38.33 \\
\hline \multirow[t]{5}{*}{2} & \multirow[t]{5}{*}{ Education } & Illiterate & 10 & 8.33 \\
\hline & & Primary school & 60 & 50.00 \\
\hline & & High school & 38 & 31.67 \\
\hline & & PUC & 9 & 7.50 \\
\hline & & Graduation and Above & 3 & 2.50 \\
\hline \multirow[t]{3}{*}{3} & \multirow[t]{3}{*}{ Family size } & Small (upto 4 members) & 43 & 35.84 \\
\hline & & Medium (5-6members) & 65 & 54.16 \\
\hline & & Big (>6members) & 12 & 10.00 \\
\hline \multirow[t]{2}{*}{4} & \multirow[t]{2}{*}{ Occupation } & Agriculture & 103 & 85.83 \\
\hline & & Agriculture and subsidiary enterprises & 17 & 14.17 \\
\hline
\end{tabular}




\begin{tabular}{|c|c|c|c|c|}
\hline \multirow[t]{3}{*}{5} & \multirow{3}{*}{$\begin{array}{l}\text { Live stock } \\
\text { possession }\end{array}$} & Small $=(1-4)$ & 82 & 68.34 \\
\hline & & Medium=(5-10) & 21 & 17.50 \\
\hline & & Large $=(>10)$ & 17 & 14.16 \\
\hline \multirow[t]{3}{*}{6} & \multirow[t]{3}{*}{ Size of land holding } & Marginal $=(<2.5 \mathrm{Ac})$ & 68 & 56.67 \\
\hline & & Small $=(2.5-5 A c)$ & 42 & 35.00 \\
\hline & & $\mathrm{Big}=(>5 \mathrm{Ac})$ & 10 & 8.33 \\
\hline \multirow[t]{3}{*}{7} & \multirow[t]{3}{*}{ Annual income } & Low $=(<35,000 . R s)$ & 33 & 27.50 \\
\hline & & Medium $=(35,000$. Rs $-77,000 \mathrm{Rs})$ & 58 & 48.33 \\
\hline & & High $=(>77,000 \mathrm{Rs})$ & 29 & 24.17 \\
\hline \multirow[t]{3}{*}{8} & \multirow[t]{3}{*}{ Farming experience } & Low $=(<4.89$ years $)$ & 11 & 9.16 \\
\hline & & Medium $=(4.89-6.87$ years $)$ & 57 & 47.50 \\
\hline & & High $=(>6.87$ years $)$ & 52 & 43.34 \\
\hline \multirow[t]{3}{*}{9} & \multirow{3}{*}{$\begin{array}{l}\text { Economic } \\
\text { Motivation }\end{array}$} & Low $=(<19.20)$ & 38 & 31.66 \\
\hline & & Medium $=(19.20-24.49)$ & 52 & 43.34 \\
\hline & & High (> 24.49) & 30 & 25.00 \\
\hline \multirow[t]{3}{*}{10} & \multirow[t]{3}{*}{ Cosmopoliteness } & Low $=(<7.58)$ & 56 & 46.67 \\
\hline & & Medium $=(7.59-12.35)$ & 41 & 34.16 \\
\hline & & High $=(>12.35)$ & 23 & 19.17 \\
\hline \multirow[t]{3}{*}{11} & \multirow[t]{3}{*}{ Extension contact } & Low $=(<2.54)$ & 45 & 37.50 \\
\hline & & Medium $=(2.54-4.51)$ & 42 & 35.00 \\
\hline & & High $=(>4.51$ & 33 & 27.50 \\
\hline \multirow[t]{3}{*}{12} & \multirow{3}{*}{$\begin{array}{l}\text { Mass media } \\
\text { participation }\end{array}$} & Low $=(<2.44)$ & 46 & 38.33 \\
\hline & & Medium $=(2.44-4.07)$ & 55 & 45.83 \\
\hline & & $\operatorname{High}=(>4.07)$ & 19 & 15.84 \\
\hline \multirow[t]{3}{*}{13} & \multirow{3}{*}{$\begin{array}{l}\text { Organizational } \\
\text { Participation }\end{array}$} & Low $=(<1.39)$ & 49 & 40.84 \\
\hline & & Medium $=(1.39-2.56)$ & 45 & 37.50 \\
\hline & & High $=(>2.56)$ & 26 & 21.66 \\
\hline \multirow[t]{3}{*}{14} & \multirow[t]{3}{*}{ Level of aspiration } & Low $=(<12.1)$ & 44 & 36.67 \\
\hline & & Medium $=(12.1-15.83)$ & 56 & 46.67 \\
\hline & & High $=(>15.83)$ & 20 & 16.66 \\
\hline
\end{tabular}

Table.2 Overall Adoption of Recommended cultivation Practices by Seasamum growers

\begin{tabular}{|c|c|c|}
\hline Adoption categories & Number & Per cent \\
\hline Low & 42 & 35.00 \\
\hline Medium & 53 & 44.17 \\
\hline High & 25 & 20.83 \\
\hline Total & $\mathbf{1 2 0}$ & $\mathbf{1 0 0 . 0 0}$ \\
\hline
\end{tabular}

Mean $=101.16 ;$ Standard Deviation $=6.07$ 
Table.3: Adoption of Specific Recommended Cultivation Practices by Seasamum growers

$(\mathrm{N}=120)$

\begin{tabular}{|c|c|c|c|c|c|c|c|}
\hline \multirow{3}{*}{$\begin{array}{l}\text { Sl. } \\
\text { No. }\end{array}$} & \multirow[t]{3}{*}{ Recommended cultivation practices } & \multicolumn{6}{|c|}{ Adoption level } \\
\hline & & \multicolumn{2}{|c|}{$\begin{array}{l}\text { Complete } \\
\text { Adoption }\end{array}$} & \multicolumn{2}{|c|}{$\begin{array}{c}\text { Partial } \\
\text { Adoption }\end{array}$} & \multicolumn{2}{|c|}{ Non-adoption } \\
\hline & & No. & $\%$ & No. & $\%$ & No. & $\%$ \\
\hline 1 & Selection of suitable soil & 78 & 65.00 & 0 & 0.00 & 42 & 35.00 \\
\hline 2 & Time of planting (April - May) & 110 & 91.67 & 10 & 8.33 & 0 & 0.00 \\
\hline 3 & Recommended varieties & 39 & 32.50 & 0 & 0.00 & 81 & 67.50 \\
\hline 4 & Recommended quantity of seed rate & 12 & 10.00 & 108 & 90.00 & 0 & 0.00 \\
\hline 5 & $\begin{array}{l}\text { Application of Recommended quantity } \\
\text { of FYM }\end{array}$ & 21 & 17.50 & 99 & 82.50 & 0 & 0.00 \\
\hline 6 & Time of Application of FYM/ Compost & 19 & 15.83 & 101 & 84.67 & 0 & 0.00 \\
\hline 7 & $\begin{array}{l}\text { Application of recommended quantity of } \\
\text { micro nutrients }\end{array}$ & 0 & 0.00 & 10 & 8.33 & 110 & 91.67 \\
\hline 8 & $\begin{array}{l}\text { Application of recommended quantity of } \\
\text { fertilizers }\end{array}$ & & & & & & \\
\hline & a. Nitrogen & 32 & 26.67 & 88 & 73.33 & 0 & 0.00 \\
\hline & b. Phosphorus & 33 & 27.70 & 87 & 72.50 & 0 & 0.00 \\
\hline & c. Potash & 17 & 14.16 & 103 & 85.83 & 0 & 0.00 \\
\hline 9 & Recommended spacing & 13 & 10.83 & 107 & 89.17 & 0 & 0.00 \\
\hline 10 & $\begin{array}{l}\text { Seed treatment with Recommended } \\
\text { fungicide }\end{array}$ & 0 & 0.00 & 20 & 16.66 & 100 & 83.34 \\
\hline 11 & Recommended depth of planting & 88 & 73.33 & 32 & 26.67 & 0 & 0.00 \\
\hline 12 & Application of recommended herbicide & 0 & 0.00 & 0 & 0.00 & 120 & 100.00 \\
\hline 13 & Inter cultivation & 83 & 69.16 & 37 & 30.84 & 0 & 0 \\
\hline 14 & Hand weeding & 99 & 82.5 & 21 & 17.50 & 0 & 0.00 \\
\hline 15 & $\begin{array}{l}\text { Thinning for maintaining plant } \\
\text { population }\end{array}$ & 79 & 65.83 & 39 & 32.50 & 2 & 1.67 \\
\hline 16 & Time of harvesting & 111 & 92.50 & 9 & 7.50 & 0 & 0.00 \\
\hline 17 & Post harvest practices & 95 & 79.17 & 25 & 20.83 & 0 & 0.00 \\
\hline 18 & Recommended yield & 31 & 25.83 & 89 & 74.17 & 0 & 0.00 \\
\hline 19 & Recommended storage practices & 37 & 30.83 & 70 & 58.33 & 13 & 10.84 \\
\hline
\end{tabular}


Table.4 Relationship between Profile characteristics of Seasamum growers and Adoption of recommended cultivation practices

\begin{tabular}{|c|l|c|}
\hline $\begin{array}{c}\text { Sl. } \\
\text { No. }\end{array}$ & \multicolumn{1}{|c|}{ Variables } & Correlation coefficient 'r' value \\
\hline $\mathbf{1}$ & Age & 0.036 \\
\hline $\mathbf{2}$ & Education & 0.128 \\
\hline $\mathbf{3}$ & Family size & 0.101 \\
\hline $\mathbf{4}$ & Occupation & $0.257^{* *}$ \\
\hline $\mathbf{5}$ & Live stock possession & $0.197^{*}$ \\
\hline $\mathbf{6}$ & Size of land holding & 0.017 \\
\hline $\mathbf{7}$ & Annual income & $0.190^{*}$ \\
\hline $\mathbf{8}$ & Farming experience & $0.240^{* *}$ \\
\hline $\mathbf{9}$ & Economic Motivation & $0.282^{* *}$ \\
\hline $\mathbf{1 0}$ & Cosmopoliteness & $0.228^{* *}$ \\
\hline $\mathbf{1 1}$ & Extension contact & 0.131 \\
\hline $\mathbf{1 2}$ & Mass media participation & 0.146 \\
\hline $\mathbf{1 3}$ & Organizational participation & 0.157 \\
\hline $\mathbf{1 4}$ & Level of aspiration & $0.206^{* *}$ \\
\hline
\end{tabular}

$(\mathrm{N}=120)$

$* *=$ significant at $1 \%$ level of probability; $*=$ significant at $5 \%$ level of probability

Table.5 Contribution of Profile characteristics of Seasamum growers and Adoption of recommended cultivation practices

$(\mathbf{N}=120)$

\begin{tabular}{|c|l|c|c|c|}
\hline $\begin{array}{c}\text { Sl. } \\
\text { No. }\end{array}$ & \multicolumn{1}{|c|}{ Variables } & $\begin{array}{c}\text { Regression } \\
\text { coefficient ' } \boldsymbol{b}^{\text {' value }}\end{array}$ & $\begin{array}{c}\text { Standard error } \\
\text { regression coefficient }\end{array}$ & 't'value \\
\hline $\mathbf{1}$ & Age & 0.223 & 0.107 & $2.076^{*}$ \\
\hline $\mathbf{2}$ & Education & 1.007 & 1.458 & 0.690 \\
\hline $\mathbf{3}$ & Family size & 6.118 & 3.831 & 0.158 \\
\hline $\mathbf{4}$ & Occupation & 0.689 & 0.884 & 0.779 \\
\hline $\mathbf{5}$ & Live stock possession & 0.425 & 1.178 & $2.376^{*}$ \\
\hline $\mathbf{6}$ & Size of land holding & 0.351 & 1.254 & 0.280 \\
\hline $\mathbf{7}$ & Annual income & -1.769 & 1.154 & -1.533 \\
\hline $\mathbf{8}$ & Farming experience & 0.169 & 0.408 & 0.415 \\
\hline $\mathbf{9}$ & Economic Motivation & 0.000 & 0.000 & $3.273 *$ \\
\hline $\mathbf{1 0}$ & Cosmopoliteness & 0.244 & 0.139 & $1.246^{*}$ \\
\hline $\mathbf{1 1}$ & Extension contact & 0.956 & 1.168 & 0.818 \\
\hline $\mathbf{1 2}$ & Mass media participation & 0.210 & 0.779 & 0.270 \\
\hline $\mathbf{1 3}$ & Organizational participation & 0.081 & 0.348 & 0.235 \\
\hline $\mathbf{1 4}$ & Level of aspiration & 0.885 & 0.280 & $3.239^{*}$ \\
\hline
\end{tabular}

$* *=$ significant at $1 \%$ level; $*=$ significant at $5 \%$ level; $\mathrm{R}^{2}=0.344 ; \mathrm{F}=3.149$ 
Table.6 Economics of Seasamum Cultivation / hectare

\begin{tabular}{|c|c|c|c|c|}
\hline $\begin{array}{l}\text { Sl. } \\
\text { No }\end{array}$ & Items & Rupees & Per cent & Rank \\
\hline \multicolumn{5}{|c|}{ I. Cost of production } \\
\hline 1 & Land preparation & 3915 & 24.82 & I \\
\hline 2 & Farmyard manure & 2900 & 18.38 & II \\
\hline 3 & Sowing & 1335 & 8.47 & V \\
\hline 4 & Seeds & 410 & 2.59 & IX \\
\hline 5 & Fertilizers & 1710 & 10.85 & III \\
\hline 7 & $\begin{array}{l}\text { Plant protection } \\
\text { measures }\end{array}$ & 1100 & 6.98 & VI \\
\hline 8 & $\begin{array}{l}\text { Weeding (hand } \\
\text { weeding) }\end{array}$ & 700 & 4.45 & VIII \\
\hline 9 & Inter cultivation & 900 & 5.70 & VII \\
\hline 10 & Harvesting & 1700 & 10.78 & IV \\
\hline 11 & $\begin{array}{l}\text { Packing and } \\
\text { transportation }\end{array}$ & 1100 & 6.98 & VI \\
\hline \multicolumn{2}{|r|}{ Total } & 15770 & & \\
\hline \multicolumn{5}{|c|}{ II. Returns } \\
\hline 1 & Yield (quintals/ha) & 4.50 & & \\
\hline 2 & Gross Returns (Rs/ ha) & $\begin{array}{c}\text { 33750/- @ } \\
\text { Rs.7,500 / } \\
\text { quintal }\end{array}$ & & \\
\hline 3 & Net Returns (Rs/ha) & $17980 /-$ & & \\
\hline 4 & Benefit - Cost Ratio & 1.14 & & \\
\hline
\end{tabular}

Table.7 Constraints expressed by Seasamum growers

\begin{tabular}{|c|l|c|c|c|}
\hline \multicolumn{2}{|c|}{ Constraints } & Number & Per cent & Rank \\
\hline No & \multicolumn{1}{|c|}{} & 108 & 90.00 & I \\
\hline $\mathbf{1}$ & Low price & 90 & 75.00 & II \\
\hline $\mathbf{2}$ & Non availability of recommended varieties & 84 & 70.00 & III \\
\hline $\mathbf{3}$ & Non availability of high yielding varieties & 81 & 67.50 & IV \\
\hline $\mathbf{4}$ & Lack of market information & 79 & 65.83 & V \\
\hline $\mathbf{5}$ & Lack of minimum support price & 76 & 63.33 & VI \\
\hline $\mathbf{6}$ & $\begin{array}{l}\text { Non availability micro nutrients in smaller } \\
\text { quantities }\end{array}$ & 68 & 56.67 & VII \\
\hline $\mathbf{7}$ & Un scientific crop insurance & & & \\
\hline
\end{tabular}

Majority of the Sesamum farmers studied up to primary school, their main occupation was agriculture, belonged to medium family size group, belonged to smaller livestock (1-4 animals) group and were marginal farmers.
This may be because of the reason that education is one of the important factor in determining status of the farmers. In addition many educational programmes were undertaken by the government to create 
awareness among the farmers about the importance of education and creation of more infrastructure facilities in the rural areas. The family size plays an controversial role under the existing situations, the agriculture may not give continues income and it is a seasonal activity and depends on allied activities. The livestock possession is becoming costly affair. Majority were marginal farmers due to fragmentation and separation of families.

As high as 44.17 per cent of Seasamum growers belonged to medium level adoption category followed by 35.00 per cent belonged to low adoption category and 20.83 per cent belonged to high adoption category. The possible reason may be that the Seasamum being grown in rainfed situation and most of the farmers treated it as an alternative crop before taking main crop. In addition it is mainly grown for consumption purpose. Bharath (2014) reported that majority of the groundnut of farmers were belonged to medium adoption category followed by low and high adoption.

Majority of the Seasamum growers completely adopted recommended cultivation practices such as, selection of suitable soil, time of planting, recommended depth of planting, inter cultivation, hand weeding, thinning for maintaining plant population, time of harvesting and post harvest practices. Further, majority of the Seasamum growers partially adopted the recommended cultivation practices such as, recommended quantity of seed rate, application of recommended quantity of FYM, time of application of FYM / compost, application of recommended quantity of nitrogen fertilizers, phosphorus and potash, recommended spacing, recommended yield and recommended storage practices. In addition, majority of the Seasamum growers not adopted the recommended cultivation practices such as, recommended varieties, application of recommended quantity of micro nutrients, seed treatment with recommended fungicide and application of recommended herbicide. The above trend of results may be attributed to the fact that farmers had adopted low cost technologies more easily than the practices which requires more investment. Raikwar and Srivastva (2013) reported that the sesame farmers ploughed their lands using power tiller and followed recommended ploughing techniques. The broadcast method for sowing sesame seeds was followed by majority of the farmers and most of the farmers used either more or less amounts of seed than that of recommendation. Majority of the farmers did not irrigate their crop, but most of them weeded their crop and did not use any pesticide to control insects. Grover and Singh(2015) revealed that there is a scope of increasing yield value of Seasamum crop by employing more human labors for plant protection measures. Hence, it can be inferred that spending more on plant protection measures, human labor for pesticide spray would be worth to further enhance the value productivity of the Seasamum crop on all farm sizes.

There was a positive and significant relationship between occupation, farming experience, economic motivation, cosmopoliteness, level of aspiration live stock possession and annual income with their adoption of recommended cultivation practices by Seasamum growers. This is because of the reason that the majority of Seasamum growers occupation is agriculture. As the farmers experience increases their knowledge on improved Seasamum technologies will also increase. Further, Cosmopoliteness will expose the individuals to the external world. In addition aspiration, economic motivation and increase in annual income motivate the farmers to adopt innovations in agriculture. Live stock 
possession helps to under take timely operations. Subhash Chand and Meena (2011) reveals that the selected independent variables viz.; education, social participation, socioeconomic status, sources of information utilization and level of knowledge influences adoption of recommended groundnut production technology. Monayem, etal (2015) reported that the adoption of improved sesame varieties was likely to be influenced by different socioeconomic factors and the estimated coefficients of the availability of family labour, availability of improved seed, cosmopolitness of the farmer, and contract with different extension sources had positive and significant impact on the adoption of improved sesame varieties. Chandrika Sharma et al., (2019) reported that the independent variables viz., education, size of land holding, land under sesame crop, socio-economic status, mass-media exposure, social participation, extension participation, scientific orientation, knowledge level and adoption level of sesamum growers in Madhya Pradesh were found statistically significant and associated with technological gap.

On an average the cost of Seasamum production per hectare was Rs.15,570 /-. The grass returns was Rs.33,750/- and net returns was Rs. 17,980 per/ hactare. The return per rupee of expenditure was 1.14 . The cost on land preparation was ranked first, farm yard manure ranked second, fertilizers ranked third, harvesting ranked fourth, sowing ranked fifth, plant protection measures and packing and transportation ranked sixth, inter cultivation ranked seventh, weeding ranked eighth and seeds ranked ninth. This may be because of the reason that now-a-days majority of farmers were not rearing draught animals due to high maintenance cost and seasamum is being grown in marginal land with low investment. Sandeep Patel (2016) reported that the total fixed cost was higher at large farms followed by marginal and small farms in groundnut cultivation.

The major constraints expressed by Seasamum growers in production of seasamum were low price, non availability of recommended varieties, non availability of high yielding varieties, lack of market information, lack of minimum support price, non availability of micro nutrients in smaller quantities and un scientific crop insurance. Grover and Singh (2015) reported the constraints faced by Seasamum growers like biotic (diseases, inset/ pest and weeds) and abiotic such as input availability constraints (seeds, 'irrigation, fertilizers, insecticides, pesticides, labour, machinery, credits), environmental constraints (drought, rain, temperature, frost) and marketing constraints (information related to price and its variability, storage losses, cost on transport, etc.)

In conclusion, majority of the farmers had adopted recommended Seasamum cultivation practices to a low - medium extent. This calls for intensive educational activities through training programmes, method demonstration, result demonstration, study tour to progress farmers field and research stations, field days and success stories in electronic and print media. Further, majority of seasamum growers expressed non availability of high yielding verities and low price. Therefore, the government may take up necessary steps for scientific profitable crop insurance, minimum support price and daily market information in website. In addition, the research stations both private and government may concentrate to release more high yielding / hybrids in Seasamum.

\section{References}

Bharat Hadiya., 2014, Adoption of Recommended Practices of Kharif 
Groundnut Growers in Saurahtra Zone of Gujarat, Gujrath Ph.D., Thesis (Unpub)., Navasari Agric. Univ.

Chandrika Sharma, N.S. Khedkar and A.K. Pande, 2019, Association between Socio-Economic, Psychological and Communicational Attributes of Sesame Growers with Technological Gap in the Recommended Sesame Production Technology, Int.J.Curr.Microbiol.App. Sci, 8(7): 1117-1119

Grover and J.M. Singh. 2015, Sesamum Cultivation in Punjab: Status, Potential and Constraints. Agricultural Economics Research Review, 20(3): 299-313.

Monayem Miah, Sadia Afroz, M. A. Rashid and S. A. M. Shiblee, 2015, Factors Affecting Adoption of Improved Sesame Technologies in Some Selected
Areas in Bangladesh: An Empirical Study. The Agriculturists 13(1): 140151.

Raikwar, R. S. and Srivastva, P. 2013, Productivity enhancement of sesame (Sesamum indicum L.) through improved production technologies. African Journal of Agricultural Research, 8(47): 6073- 6078.

Sandeep Patel, 2016 Production and Marketing of Groundnut in Mahasamund District of Chhattisgarh: an Economic Analysis. M.Sc. (Agri.) Thesis, (Unpublished), Indira Gandhi krishi vishwavidayalaya, Raipur.

Subhash Chand and K.C. Meena (2011) Correlates of adoption of groundnut production technology by the farmers. Raj. J. Extn. Edu. 19: 125-127.

\section{How to cite this article:}

Shivaramu, K., M.A. Murthy and Papanna, N. 2019. Economics and Adoption of Recommended Cultivation Practices by Seasamum Growers. Int.J.Curr.Microbiol.App.Sci. 8(08): 2516-2526. doi: https://doi.org/10.20546/ijcmas.2019.808.293 